\title{
Flow rate and hydrochemistry in areas of sand mining activities
}

\author{
D. M. Bonotto ${ }^{1} \&$ E. G. Oliveira ${ }^{2}$ \\ ${ }^{1}$ Departamento de Petrologia e Metalogenia, \\ Instituto de Geociências e Ciências Exatas-UNESP, Rio Claro, Brazil \\ ${ }^{2}$ Departamento de Geologia Aplicada, \\ Instituto de Geociências e Ciências Exatas-UNESP, Rio Claro, Brazil
}

\begin{abstract}
This investigation reports the results of a study realized in areas related to the development of sand mining activities, which belong to CRS-Mineração Indústria e Comércio Ltd. and Sibelco Mineração Ltd. Both areas are located around Analândia municipality, nearly in the center of São Paulo State, Brazil. Flow rate and hydrochemical analyses were realized over different periods of time, with the aim of evaluating the possibility of release of several constituents to the liquid phase, which may be a source of pollution of the surface hydrological resources. This is because some tributaries from the Corumbataí River may be suffering contamination, implying on the impoverishment of the water quality that is a very important resource in the region, as it is extensively used for drinking purposes, among others.
\end{abstract}

Keywords: sand mining activities, flow rate, hydrochemistry, water quality.

\section{Introduction}

The study of discharge in hydrographic basins is important because it allows one to evaluate the water volume circulating annually in the basin. Consequently, it is possible to obtain the dilution capacity of effluents released into drainage during the development of industrial/mining activities, among others. It also permits one to know the depuration ability of rivers and streams during eventual pollution events. For instance, if occurs pronounced dry periods, then, in principle, it may be possible estimate the minimum flow rate of the water body, as well the dilution rate of pollutants released into it. 
The São Paulo State in Brazil has a great diversity of problems able to cause the water pollution in hydrographic basins, as the sand mining activities in Depressão Periférica geomorphological province that involve the use of several chemicals for the treatment of natural sand like $\mathrm{HCl}, \mathrm{H}_{2} \mathrm{SO}_{4}, \mathrm{NaOH}$ and $\mathrm{Na}_{2} \mathrm{SiO}_{4}$. This study focuses two areas, the first belonging to CRS-Mineração Indústria e Comércio Ltd. and the second to Sibelco Mineração Ltd., both located about 5-6 km from Analândia city, nearly in the center of São Paulo State (Fig. 1). They are situated within the Corumbataí river basin that occurs in an eroded belt in the cuestas zone of the Depressão Periférica geomorphological province [1].

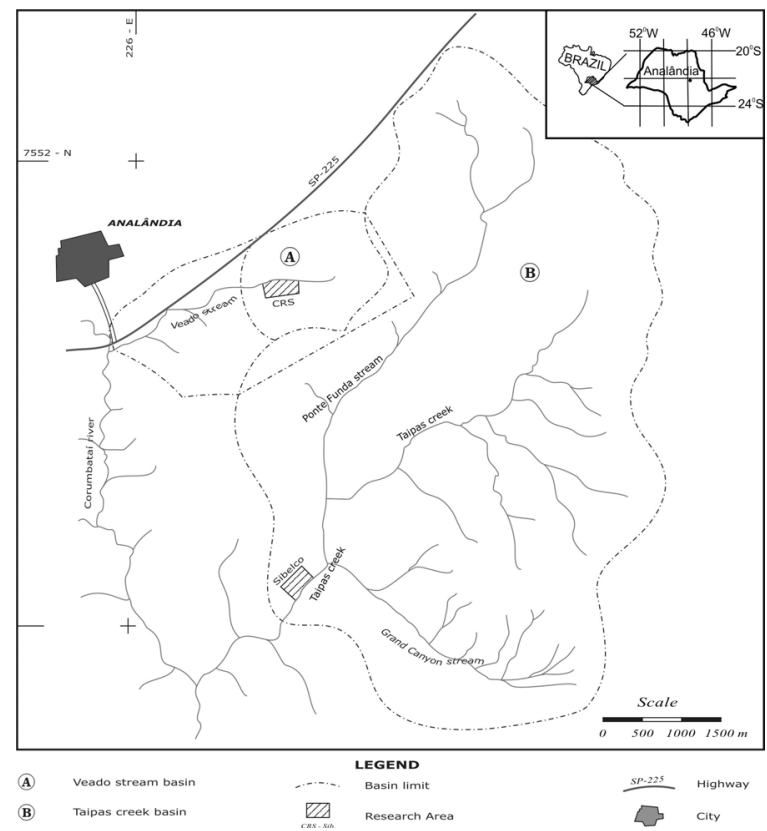

Figure 1: Location of the Analândia city at São Paulo State, Brazil, and sketch map of the areas here studied.

\section{General features of the studied areas}

The Corumbataí river basin extends over an area of about $1,581 \mathrm{~km}^{2}$. It is a sub-basin of the giant Paraná sedimentary basin, whose area is about $1,000,000 \mathrm{~km}^{2}$ in Brazilian surface [2]. Several stratigraphic units of the Paraná basin (Paleozoic - Cenozoic) crop-out in it [3]: the Tubarão Group comprising the Itararé Subgroup (sandstone, conglomerates, diamictites, tillites, siltstone, shale and rythmites) and Tatuí Formation (siltstone, shale, silex and sandstone with local concretions); the Passa Dois Group comprising the Irati Formation (siltstone, mudstone, black betuminous shale and limestone) and Corumbataí Formation (mudstone, shale and siltstone); the São Bento Group comprising the Pirambóia Formation (sandstone, shale and muddy sandstone), Botucatu Formation (sandstone and muddy sandstone), Serra Geral Formation (basalts 
and diabases) and related basic intrusives; different types of Cenozoic covers like the recent deposits, terrace sediments and the Rio Claro Formation (sandstone, conglomerate sandstone and muddy sandstone).

Among the major types of soils occurring in the Corumbataí river basin, yellow-red podzols and latossols cover about $65 \%$ of the area of the basin [4]. The Corumbataí River flows from the cuestas zone to the confluence with the Piracicaba River. Rio Claro City is the most important municipality in the basin, with 170,000 inhabitants.

The climate of the region is tropical, being characterized by wet summer (October through March) and dry winter (April through September) [5]. The area often has 55 - 65 days of rain per year, with more than $80 \%$ of the precipitation falling between October and March [6]. The flow rate at Corumbataí River is directly dependant on rainfall.

Table 1: $\quad$ Parameters related to the sub-basins investigated in this paper.

\begin{tabular}{lll}
\hline \multicolumn{1}{c}{ Parameter } & & \multicolumn{1}{c}{ Sub-basin } \\
\hline Name - Company & North- CRS & South- Sibelco \\
Main drainage & Veado stream & Taipas creek \\
Dominant basin & Corumbataí River & Corumbataí River \\
UGRHI & 14 & 14 \\
Axial length $(\mathrm{km})$ & 2.1 & 6.2 \\
Average width $(\mathrm{km})$ & 15 & 5 \\
Área $\left(\mathrm{km}^{2}\right)$ & 2.3 & 30.6 \\
Perimeter $(\mathrm{km})$ & 5.4 & 27.4 \\
Average ground slope $(\%)$ & 2.3 & 2 \\
Total length of the drainage $(\mathrm{km})$ & 1.35 & 41.55 \\
Order of the drainage & $1 \mathrm{st}$ & 4 th \\
Density of the drainage $\left(\mathrm{km} / \mathrm{km}^{2}\right)$ & 0.59 & 1.35 \\
Surface flow coefficient $(\mathrm{km})$ & 0.42 & 0.18 \\
Shape factor $-\mathrm{K}_{\mathrm{f}}-\left(\mathrm{km}{ }^{2} / \mathrm{km}^{2}\right)$ & 0.51 & 0.78 \\
Gravelius coefficient $-\mathrm{K}_{\mathrm{c}}-($ dimensionless $)$ & 1.02 & 1.38 \\
Mean annual discharge $-\mathrm{Q}_{\mathrm{m}}-(\mathrm{L} / \mathrm{s})$ & 24.9 & 337.5 \\
Minimum annual discharge for consecutive 7 days - $\mathrm{Q}_{7,10}-5.56$ & 75.43 \\
(L/s) & & \\
\hline
\end{tabular}

Both areas investigated in this study are inserted within of different subbasins of the Corumbataí river basin, here named: North Area (basin related to Veado stream) and South Area (basin related to Taipas creek (Fig. 1). The Taipas creek is the main drainage in South Area; its name changes to Ponte Funda stream, about $1 \mathrm{~km}$ upstream from the sand mining area. Its general flow direction is NE-SW, flowing towards SW up to the confluence with the Corumbataí River. The ground slope is about $1.7 \%$, and slightly lower $(1.3 \%)$ in front of the sand mining area. The Veado stream is the main drainage in North Area, which also flows in the NE-SW direction. The general ground slope is 
about $2.3 \%$, and the area of this sub-basin is $2.26 \mathrm{~km}^{2}$. Table 1 describes the main characteristics of these two sub-basins.

The parameters expressed in Table 1 were defined elsewhere [7-9], as follows:

- UGRHI: the code means Unit for the Management of Hydrological Resources, and identifies all hydrographic basins in São Paulo State, Brazil [8]. It corresponds to 14 in the studied area.

- Axial length: it corresponds to the linear distance of the main axis of the basin that is measured from the point of discharge of effluent up to the more distant of the basin.

- Average width: it corresponds to the average distance of the transverse to the axial length of the basin.

- Area: it corresponds to the estimated area of the basin.

- Perimeter: it corresponds to the linear extension limiting the basin.

- Average ground slope: it corresponds to the average ground slope of the main axis of the drainage that is measured in percentage considering the more elevated and depressed points.

- Total length of the drainage: it corresponds to the summation of the linear lengths of all drainages occurring in the basin.

- Order of the drainage: it corresponds to the ramification degree of the drainage.

- Density of the drainage: this parameter compares the total length of the drainage $(\mathrm{L}$, in $\mathrm{km})$, with the basin area $\left(A\right.$, in $\left.\mathrm{km}^{2}\right)$, i.e. $\mathrm{D}_{\mathrm{d}}=\mathrm{L} / \mathrm{A}$. Higher values imply on higher amount of water in the basin, facilitating the flooding and, consequently, not favoring the flow. Typical values are: $\mathrm{D}_{\mathrm{d}}=3$ (dense drainage), $\mathrm{D}_{\mathrm{d}}=1-2$ (average drainage), and $\mathrm{D}_{\mathrm{d}}<1$ (poor drainage).

- Surface flow coefficient: this parameter evaluates the average distance of the rainwater flow over the soil of the basin, i.e. it is the reciprocal of the density of the drainage. It may be estimated by the equation $\mathrm{E}_{\mathrm{s}}=\mathrm{A} / 4 \mathrm{~L}$, where, $\mathrm{E}_{\mathrm{s}}=$ surface flow, $\mathrm{A}=$ basin area, and $\mathrm{L}=$ total length of the drainage.

- Shape factor: this parameter focuses the basin shape, relating the basin area (A) and the total length of the drainage $(\mathrm{L})$ by the equation $\mathrm{K}_{\mathrm{f}}=\mathrm{A} / \mathrm{L}^{2}$. Higher $\mathrm{K}_{\mathrm{f}}$ values (higher than 2 ) tend to facilitate flooding.

- Gravelius coefficient: this parameter relates the perimeter of the basin $(\mathrm{P})$ with a circle possessing an area equivalent to that of the basin (A), according to the equation $\mathrm{K}_{\mathrm{c}}=0.28 \mathrm{P} /(\mathrm{A})^{1 / 2}$, where 0.28 is a constant. The resulting value is dimensionless, which generally exceeds 1 . Values close to 1 imply that the basin shape practically corresponds to a circle, favoring the occurrence of flooding. In this study, the North Area tends to flood more easily than the South Area, according to $\mathrm{K}_{\mathrm{c}}$ values.

\section{Flow rate at the studied areas}

The discharge in North Area was measured in situ by the traditional technique that considers the variation of the of water level height in a certain position of the stream where the transversal section is known. The discharge in South Area was measured through a limnigraph settled in a local of known transversal section, 
and where continuous readings supplied the data of the variations of the water level that are necessary for evaluating the discharge.

Table 2: Parameters related to hydrographic basins in São Paulo State, Brazil [8].

\begin{tabular}{|c|c|c|c|c|c|c|c|c|c|c|}
\hline \multirow[t]{3}{*}{ Region } & \multicolumn{2}{|c|}{$\mathrm{Q}_{\mathrm{m}}$} & \multicolumn{6}{|c|}{$\begin{array}{c}X_{t} \\
\text { Returning Period (vears) }\end{array}$} & \multicolumn{2}{|c|}{$\mathrm{A} / \mathrm{B}$ values } \\
\hline & \multirow[t]{2}{*}{$\mathrm{a}$} & \multirow[t]{2}{*}{$\mathrm{b}$} & \multicolumn{6}{|c|}{ Returning Period T (years) } & \multirow[t]{2}{*}{ A } & \multirow[t]{2}{*}{ B } \\
\hline & & & 10 & 15 & 20 & 25 & 50 & 100 & & \\
\hline A & -22.14 & 0.0292 & 0.708 & 0.674 & 0.655 & 0.641 & 0.607 & 0.581 & 0.3532 & 0.0398 \\
\hline B & -29.47 & 0.0315 & 0.708 & 0.674 & 0.655 & 0.641 & 0.607 & 0.581 & 0.4174 & 0.0426 \\
\hline $\mathrm{C}$ & -29.47 & 0.0315 & 0.748 & 0.723 & 0.708 & 0.698 & 0.673 & 0.656 & 0.4174 & 0.0426 \\
\hline D & -22.14 & 0.0292 & 0.708 & 0.674 & 0.655 & 0.641 & 0.607 & 0.581 & 0.5734 & 0.0329 \\
\hline $\mathrm{E}$ & -22.14 & 0.0292 & 0.708 & 0.674 & 0.655 & 0.641 & 0.607 & 0.641 & 0.4775 & 0.0330 \\
\hline $\mathrm{F}$ & -22.14 & 0.0292 & 0.708 & 0.674 & 0.655 & 0.641 & 0.641 & 0.641 & 0.6434 & 0.0252 \\
\hline G & -26.23 & 0.0278 & 0.632 & 0.588 & 0.561 & 0.543 & 0.496 & 0.461 & 0.4089 & 0.0332 \\
\hline $\mathrm{H}$ & -29.47 & 0.0315 & 0.748 & 0.723 & 0.708 & 0.698 & 0.673 & 0.656 & 0.4951 & 0.0279 \\
\hline I & -29.47 & 0.0315 & 0.708 & 0.674 & 0.655 & 0.641 & 0.607 & 0.581 & 0.6276 & 0.0283 \\
\hline $\mathrm{J}$ & -29.47 & 0.0315 & 0.708 & 0.674 & 0.655 & 0.641 & 0.607 & 0.581 & 0.4741 & 0.0342 \\
\hline K & -26.23 & 0.0278 & 0.689 & 0.658 & 0.639 & 0.626 & 0.595 & 0.572 & 0.4591 & 0.0279 \\
\hline $\mathrm{L}$ & -26.23 & 0.0278 & 0.759 & 0.733 & 0.717 & 0.706 & 0.677 & 0.654 & 0.6537 & 0.0267 \\
\hline $\mathrm{M}$ & -4.62 & 0.0098 & 0.759 & 0.733 & 0.717 & 0.717 & 0.677 & 0.654 & 0.6141 & 0.0257 \\
\hline $\mathrm{N}$ & -26.23 & 0.0278 & 0.689 & 0.658 & 0.639 & 0.626 & 0.595 & 0.572 & 0.4119 & 0.0295 \\
\hline $\mathrm{O}$ & -26.23 & 0.0278 & 0.689 & 0.658 & 0.639 & 0.626 & 0.595 & 0.572 & 0.3599 & 0.0312 \\
\hline $\mathrm{P}$ & -26.23 & 0.0278 & 0.619 & 0.577 & 0.552 & 0.535 & 0.492 & 0.459 & 0.3599 & 0.0312 \\
\hline Q & -4.62 & 0.0098 & 0.633 & 0.572 & 0.533 & 0.504 & 0.426 & 0.358 & 0.6537 & 0.0267 \\
\hline $\mathrm{R}$ & -4.62 & 0.0098 & 0.661 & 0.629 & 0.610 & 0.598 & 0.568 & 0.548 & 0.6141 & 0.0257 \\
\hline $\mathrm{S}$ & -4.62 & 0.0098 & 0.661 & 0.629 & 0.610 & 0.598 & 0.568 & 0.546 & 0.5218 & 0.0284 \\
\hline $\mathrm{T}$ & -4.62 & 0.0098 & 0.661 & 0.629 & 0.610 & 0.598 & 0.568 & 0.546 & 0.4119 & 0.0295 \\
\hline $\mathrm{U}$ & -4.62 & 0.0098 & 0.594 & 0.518 & 0.469 & 0.433 & 0.330 & 0.240 & 0,4119 & 0.0295 \\
\hline
\end{tabular}

However, despite these direct measurements, alternative approaches were utilized to estimate the discharge, which have been officially adopted in São Paulo State and are based on the technique suggested by [8]. The method depends on the frequency of a certain discharge, i.e. the number of occurrences of that flow rate in a time interval and also of its reciprocal, i.e. the returning period (time interval between two occurrences of a certain discharge). Two types of flow rate may be estimated: the mean annual discharge, $\mathrm{Q}_{\mathrm{m}}$ (in $\mathrm{L} / \mathrm{s}$ ), and the minimum annual discharge for consecutive 7 days over a returning period $(\mathrm{T})$ of 10 years, $\mathrm{Q}_{7,10}$ (in $\left.\mathrm{L} / \mathrm{s}\right)$.

According to [8], the steps to evaluate $Q_{m}$ are:

a) to find $P$, the average annual precipitation in the area (1340 $\mathrm{mm}$ in this study); 
b) to find the type of hydrographic basin according to the general classification for São Paulo State (in the present study, the Corumbataí river basin belongs to Tietê-Piracicaba hydrological region, which is represented by the letter "G");

c) to estimate $\mathrm{A}$, the basin area (in $\mathrm{km}^{2}$ );

d) to find other parameters necessary for estimating $\mathrm{Q}_{\mathrm{m}}$, according to the equation $\mathrm{Q}_{\mathrm{m}}(\mathrm{L} / \mathrm{s})=(\mathrm{a}+\mathrm{b} \times \mathrm{P}) \times \mathrm{A}$. In this study, $\mathrm{a}$ and $\mathrm{b}$ correspond to -26.23 and 0.0278, respectively (Table 2). Thus, $\mathrm{Q}_{\mathrm{m}}=24.90 \mathrm{~L} / \mathrm{s}$ in the North Area, and $\mathrm{Q}_{\mathrm{m}}=337.5 \mathrm{~L} / \mathrm{s}$ in the South Area. This non-direct discharge evaluation in Taipas creek is reasonable if compared with values directly measured, as shown in Table 3. The flow rate of effluents released into Taipas creek is $8-9 \mathrm{~L} / \mathrm{s}$, that is significantly lower than the discharge of the drainage, as expected.

Table 3: $\quad$ Comparison of measured and calculated flow rates at Taipas creek.

\begin{tabular}{ccccc}
\hline Year & Month & $\begin{array}{c}\text { Measured discharge } \\
(\mathrm{L} / \mathrm{s})\end{array}$ & $\begin{array}{c}\text { Calculated discharge } \\
(\mathrm{L} / \mathrm{s})\end{array}$ & $\begin{array}{c}\text { Difference between } \\
\text { the values }\end{array}$ \\
\hline & & Taipas creek & \\
1993 & September & 407.5 & & \\
1994 & march & 538.0 & 337.5 & $9.5 \%$ \\
1994 & October & 174.0 & \\
& average & 373.1 & \\
& & Decantation pools and tanks drain & \\
1993 & September & 8.4 & & \\
1994 & march & 9.2 & & \\
\hline
\end{tabular}

It is well known the fact that the rainfall can vary along each year, as well along several years, where the events may repeat regularly or randomly. In the case of hydrographic basins, it is important to calculate the probability of occurrence of periods of severe dry periods and the minimum expected discharge in these periods, as it may be critical the dilution of any pollutant in the basin. These factors may be calculated for returning periods of 10, 15, 20, 25, 50 or 100 years. Additionally, the minimum discharge is calculated for time intervals of 7 , 30,60 or 180 days. Obviously, these calculations depend on systematic reports performed for the basins in São Paulo State, however, this is a situation commonly not verified. According to [8], the equation for evaluating $\mathrm{Q}_{7,10}$ is $\mathrm{Q}_{7,10}=\mathrm{X}_{\mathrm{T}} \times \mathrm{Q}_{\mathrm{m}}(\mathrm{A}+\mathrm{B}) \times 0.80$, where $\mathrm{X}_{\mathrm{T}}$ is the returning period $\mathrm{T}$ (for 10 years $=0.632$ ) (Table 2), $\mathrm{A}$ and $\mathrm{B}$ are 0.4089 and 0.0332 , respectively (Table 2), and 0.80 is the relation between the average minimum annual discharge for consecutive 7 days $\left(\mathrm{Q}_{7}\right)$ and the average minimum annual discharge for one month $\left(\mathrm{Q}_{\mathrm{M}}\right)$. Thus, $\mathrm{Q}_{7,10}=5.56 \mathrm{~L} / \mathrm{s}$ in the North Area, and $\mathrm{Q}_{7,10}=75.43 \mathrm{~L} / \mathrm{s}$ in the South Area.

\section{Hydrochemical data at the studied areas}

Hydrochemical monitoring was performed at both investigated areas with the aim of characterizing the quality of the surface waters. Two sampling points upstream and downstream of each area containing the effluents were selected, plus one point where the effluents in decantation pools and tanks are discharged into Taipas creek (South Area) (Figs. 2 and 3). This sampling point provides 
information about eventual environmental impact related to 12 decantation tanks exhibiting areas between 2,800 and $16,000 \mathrm{~m}^{2}$ that were installed in the ground of South Area for containing the wastes of the sand mining activities.

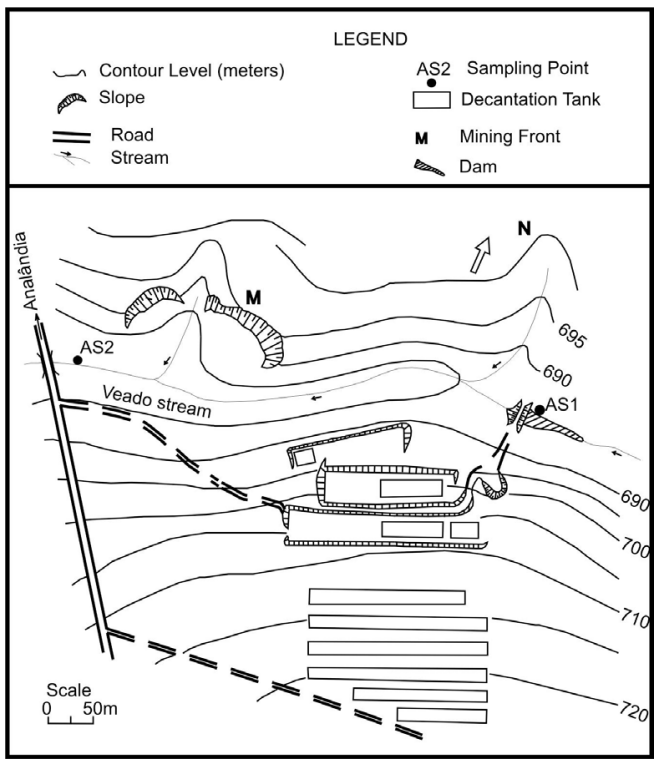

Figure 2: Location of the sampling points and decantation pools/tanks at North Area.

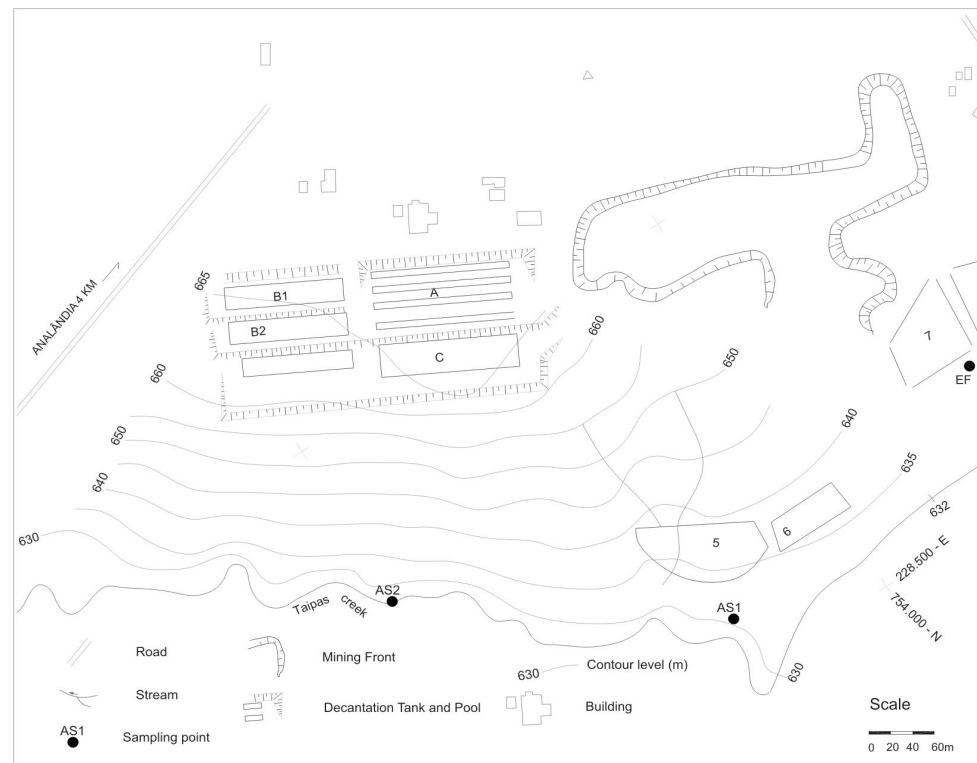

Figure 3: Location of the sampling points and decantation pools/tanks at South Area [10]. 
Table 4: $\quad$ Results of analyses for samples collected at North Area.

\begin{tabular}{cccccc}
\hline Parameter & Unit & AS1 & AS1 & AS2 & AS2 \\
\hline Sampling date & - & $12 / 04 / 1991$ & $04 / 13 / 1993$ & $12 / 04 / 1991$ & $04 / 13 / 1993$ \\
Temperature & ${ }^{\circ} \mathrm{C}$ & 28 & 26 & 26 & 23 \\
DO & $\mathrm{mg} / \mathrm{L}$ & 7.5 & - & 8.0 & - \\
$\mathrm{pH}$ & - & 4.4 & 5.5 & 4.8 & 5.9 \\
Conductivity & $\mu \mathrm{S} / \mathrm{cm}$ & 40 & - & 40 & - \\
COD & $\mathrm{mg} / \mathrm{L}$ & $<0.10$ & $<0.10$ & $<0.10$ & $<0.10$ \\
Dry residue & $\mathrm{mg} / \mathrm{L}$ & $<1.0$ & 24 & $<1.0$ & 20 \\
Silicon & $\mathrm{mg} / \mathrm{L}$ & 3.70 & 0.29 & 3.30 & 1.59 \\
Bicarbonate & $\mathrm{mg} / \mathrm{L}$ & 8 & - & 12 & - \\
Sulfate & $\mathrm{mg} / \mathrm{L}$ & $<0.10$ & 1.33 & $<0.10$ & 0.10 \\
Chloride & $\mathrm{mg} / \mathrm{L}$ & 0.40 & $<0.01$ & 0.60 & $<0.01$ \\
Fluoride & $\mathrm{mg} / \mathrm{L}$ & 0.05 & 0.47 & 0.04 & 0.36 \\
Nitrate+Nitrite & $\mathrm{mg} / \mathrm{L}$ & 0.03 & 0.08 & 0.03 & 0.07 \\
Ammonium & $\mathrm{mg} / \mathrm{L}$ & $<0.20$ & $<0.20$ & $<0.20$ & $<0.20$ \\
Phosphate & $\mathrm{mg} / \mathrm{L}$ & $<0.10$ & $<0.10$ & $<0.10$ & $<0.10$ \\
Boron & $\mathrm{mg} / \mathrm{L}$ & $<0.02$ & - & $<0.02$ & - \\
Aluminum & $\mathrm{mg} / \mathrm{L}$ & $<0.10$ & $<0.10$ & $<0.10$ & $<0.10$ \\
Sodium & $\mathrm{mg} / \mathrm{L}$ & 0.10 & - & 0.10 & - \\
Potassium & $\mathrm{mg} / \mathrm{L}$ & 0.30 & - & 0.20 & - \\
Calcium & $\mathrm{mg} / \mathrm{L}$ & 0.10 & - & 0.10 & - \\
Magnesium & $\mathrm{mg} / \mathrm{L}$ & $<0.10$ & - & $<0.10$ & - \\
Barium & $\mathrm{mg} / \mathrm{L}$ & $<0.02$ & - & $<0.02$ & - \\
Cadmium & $\mathrm{mg} / \mathrm{L}$ & $<0.02$ & - & $<0.02$ & - \\
Lead & $\mathrm{mg} / \mathrm{L}$ & $<0.10$ & - & $<0.10$ & - \\
Chromium & $\mathrm{mg} / \mathrm{L}$ & $<0.05$ & - & $<0.05$ & - \\
Copper & $\mathrm{mg} / \mathrm{L}$ & $<0.02$ & - & $<0.02$ & - \\
Iron & $\mathrm{mg} / \mathrm{L}$ & $<0.02$ & $<0.01$ & $<0.02$ & $<0.01$ \\
Manganese & $\mathrm{mg} / \mathrm{L}$ & $<0.02$ & 0.02 & $<0.02$ & 0.03 \\
Zinc & $\mathrm{mg} / \mathrm{L}$ & $<0.02$ & - & $<0.02$ & - \\
Nickel & $\mathrm{mg} / \mathrm{L}$ & $<0.02$ & - & $<0.02$ & - \\
\hline
\end{tabular}

The samples were stored in polyethylene or borosilicate bottles, and standard analytical techniques were used for obtaining the parameters established by São Paulo State Register 997 (published on 31 May 1976) and National Register CONAMA 20 (published on 18 June 1986) for defining the quality of fresh waters and possible release of effluents into the waters. The methods comprised gravity separation, dilution and incubation, methyl orange end-point titration, potentiometry, ion selective electrode, atomic absorption spectrometry, colorimetry, and atomic emission spectrometry associated to inductively coupled Ar plasma (ICP-AES), among others.

Portable meters were used for in situ measurements of temperature, $\mathrm{pH}$, and dissolved oxygen (DO), with the equipment calibration being performed immediately before the analyses. The settleable solids in the samples were evaluated by a clear borosilicate glass Imhoff cone $0-1000 \mathrm{~mL}$ calibrated. The COD (Chemical Oxygen Demand) and BOD (Biochemical Oxygen Demand) were also evaluated from DO data. When necessary, the samples were preserved with appropriate acids and filtered through $0.45 \mu \mathrm{m}$ membranes. 
Table 4 reports the results of analyses for samples collected at North Area. The values found for $\mathrm{NH}_{4}, \mathrm{P}, \mathrm{B}, \mathrm{Al}, \mathrm{Mg}, \mathrm{Ba}, \mathrm{Cd}, \mathrm{Pb}, \mathrm{Cr}, \mathrm{Cu}, \mathrm{Fe}, \mathrm{Zn}$, and $\mathrm{Ni}$ are below the detection limits of the analytical techniques utilized. Bicarbonate is the major anion dissolved in the waters. With the exception of $\mathrm{pH}$, all other values obtained for the investigated parameters do not suggest the occurrence of any environmental impact related to the sand mining activities. The $\mathrm{pH}$ values could be attributed to some anthropogenic input, however, $\mathrm{Na}^{+}, \mathrm{Cl}^{-}$, and $\mathrm{SO}_{4}{ }^{2-}$, which are potentially important to affect the area, are present in very low concentrations, as confirmed by the low values of conductivity and dry residue. Thus, the water composition mainly reflects the composition of rainwater with small amounts of silica added from contact with rocks and soils.

Table 5: $\quad$ Results of analyses for samples collected at South Area.

\begin{tabular}{cccccccccc}
\hline Parameter & Unit & AS1 & AS1 & AS1 & AS2 & AS2 & EF & EF & EF \\
\hline Sampling date & & $09 / 06 /$ & $03 / 31 /$ & $10 / 14 /$ & $09 / 06 /$ & $03 / 31 /$ & $09 / 06 /$ & $03 / 31 /$ & $10 / 14 /$ \\
& & 1993 & 1994 & 1994 & 1993 & 1994 & 1993 & 1994 & 1994 \\
Temperature & ${ }^{\circ} \mathrm{C}$ & 25 & - & 27 & - & - & - & - & 31 \\
DO & $\mathrm{mg} / \mathrm{L}$ & 7.8 & 8.5 & 6.5 & 7.6 & 3.8 & 8.0 & 3.8 & 6.5 \\
$\mathrm{pH}$ & - & 6.3 & 6.5 & 6.4 & 7.0 & 6.3 & 7.3 & 6.6 & 4.7 \\
Conductivity & $\mu \mathrm{S} / \mathrm{cm}$ & 19.1 & 19.1 & 34.0 & 34.2 & 48.3 & 139.4 & 138.9 & 220.0 \\
Iron & $\mathrm{mg} / \mathrm{L}$ & 0.06 & 0.20 & 0.16 & 0.10 & 0.10 & 0.60 & $<0.02$ & 0.23 \\
Aluminum & $\mathrm{mg} / \mathrm{L}$ & $<0.10$ & $<0.10$ & 0.08 & $<0.10$ & $<0.10$ & 1.00 & $<0.10$ & 0.08 \\
Calcium & $\mathrm{mg} / \mathrm{L}$ & 1.20 & 4.10 & 1.50 & 1.50 & 1.30 & 0.30 & 0.50 & 0.68 \\
Lead & $\mathrm{mg} / \mathrm{L}$ & $<0.10$ & $<0.10$ & 0.01 & $<0.10$ & $<0.10$ & $<0.10$ & $<0.10$ & 0.02 \\
Magnesium & $\mathrm{mg} / \mathrm{L}$ & 0.40 & 0.40 & 0.67 & 0.60 & 0.50 & 0.08 & 0.20 & 0.32 \\
Nickel & $\mathrm{mg} / \mathrm{L}$ & 0.02 & $<0.02$ & $<0.02$ & 0.02 & $<0.02$ & 0.02 & $<0.02$ & $<0.02$ \\
Silver & $\mathrm{mg} / \mathrm{L}$ & $<0.10$ & $<0.10$ & $<0.10$ & $<0.10$ & $<0.10$ & $<0.10$ & $<0.10$ & $<0.10$ \\
COD & $\mathrm{mg} / \mathrm{L}$ & 9.20 & 5.81 & $<1.00$ & 18.40 & 8.14 & 9.20 & 7.22 & $<1.00$ \\
BOD & $\mathrm{mg} / \mathrm{L}$ & 12.11 & 0.94 & $<0.05$ & 4.20 & 0.47 & 9.92 & 3.29 & $<0.05$ \\
Dry residue & $\mathrm{mg} / \mathrm{L}$ & 52 & 78 & 18 & 34 & 46 & 98 & 90 & 56 \\
Settleable residue & $\mathrm{mg} / \mathrm{L}$ & 12.9 & 7.8 & $<0.01$ & $<0.01$ & 8.8 & 85.5 & 1.2 & 1.0 \\
\hline
\end{tabular}

Table 5 reports the results of analyses for samples collected at South Area. The values obtained for major cations $\mathrm{Ca}$ and $\mathrm{Mg}$ are low, also indicating influence of the rainwater on the chemical composition of the surface waters. The $\mathrm{pH}$ values are within the range of the values established by the National Register CONAMA 20, except for the effluent sample collected in 14 October 1994. The dissolved oxygen values are within the range of the values established by the National Register CONAMA 20, except for the surface water and effluent samples collected in 31 March 1994. These data are indicative of anthropogenic input of pollutants in Taipas creek. The same is evidenced by DBO data from samples of the surface water and effluents collected in 6 September 1993. The 
values obtained for the settleable solids, dry residue ( total dissolved solids), Fe, and $\mathrm{Ni}$ in the effluents are lower than the maximum established by the National Register CONAMA 20. The value obtained for aluminum in the effluents collected in 6 September 1993 is higher than the maximum established by the National Register CONAMA 20. The values found for $\mathrm{Pb}$ and $\mathrm{Ag}$ are below the detection limits of the analytical techniques utilized. Thus, the data set is indicative of the occurrence of some environmental impact related to the sand mining activities.

Therefore, the results of this study indicated that the waste disposal areas related to the treatment of sand for industrial purposes may be a source of contaminants to the hydrologic environment. Flow rate and hydrochemical analyses proved to be important tools to investigate both areas from São Paulo State, Brazil, here investigated.

\section{References}

[1] Penteado, M.M., Geomorfologia do setor centro-ocidental da Depressão Periférica paulista. Série teses e monografias, 22, IGEOG/USP, São Paulo, 1976.

[2] França, A.B. \& Potter, P.E., Stratigraphy, Depositional Environment and Reservoir Analysis from Itararé Group, Paraná basin (Part 1). Petrobrás Geociences Bulletin, 2 (2/4), pp. 147-192, 1988.

[3] IPT (Instituto de Pesquisas Tecnológicas do Estado de São Paulo), Mapa Geológico do Estado de São Paulo. Monografias: São Paulo, 1981.

[4] Köffler, N.F., Diagnósticos do uso agrícola das terras da Bacia do Rio Corumbataí, SP. Report, IGCE-UNESP: Rio Claro, 1993.

[5] Inácio, A. \& Santos, M.J.Z., Características climáticas de Rio Claro. Boletim de Geografia Teorética, 18 (35-36): pp. 87-104, 1998.

[6] Bonotto, D.M. \& Mancini, L.H., Estudo hidroquímico e isotópico dos aqüíferos de Rio Claro (SP). Geochim. Brasil., 6 (2): pp. 153-167, 1992.

[7] Pinto, N.L.S., Holtz, A.C.T. \& Martins, J.A., Hidrologia de superfície, Edgard Blücher: São Paulo, 1973.

[8] Liazi, A., Conejo, J.G.L, Palos, J.C.F \& Cintra, P.S. Regionalização hidrológica no Estado de São Paulo, Revista Águas e Energia Elétrica, 14 (5), pp. 4-10, 1988.

[9] Esteves, F.A., Fundamentos de limnologia, Interciência: Rio de Janeiro, 1988.

[10] Tandel, R.Y, Caracterização do Arenito Pirambóia da Fazenda São João em Analândia (SP) e sua utilização industrial. Ms. Dis., IG-USP: São Paulo, 1993. 